\title{
Current Advances in Immunotherapy for Glioblastoma
}

\author{
Abigail L. Mende ${ }^{1} \cdot$ Jessica D. Schulte ${ }^{1,2} \cdot$ Hideho Okada $^{1,3,4}$ (D) $\cdot$ Jennifer L. Clarke ${ }^{1,2,5}$
}

Accepted: 17 December 2020 / Published online: 26 January 2021

(C) The Author(s) 2021

\begin{abstract}
Purpose of Review This review seeks to inform oncology clinicians and researchers about the development of novel immunotherapies for the treatment of glioblastoma. An enumeration of ongoing and recently completed clinical trials will be discussed with special attention given to current technologies implemented to overcome central nervous system-specific challenges including barriers to the peripheral immune system, impaired antigen presentation, and $\mathrm{T}$ cell dysfunction.

Recent Findings The success of immunotherapy in other solid cancers has served as a catalyst to explore its application in glioblastoma, which has limited response to other treatments. Recent developments include multi-antigen vaccines that seek to overcome the heterogeneity of glioblastoma, as well as immune checkpoint inhibitors, which could amplify the adaptive immune response and may have promise in combinatorial approaches. Additionally, oncolytic and retroviruses have opened the door to a plethora of combinatorial approaches aiming to leverage their immunogenicity and/or ability to carry therapeutic transgenes.

Summary Treatment of glioblastoma remains a serious challenge both with regard to immune-based as well as other therapeutic strategies. The disease has proven to be highly resistant to treatment due to a combination of tumor heterogeneity, adaptive expansion of resistant cellular subclones, evasion of immune surveillance, and manipulation of various signaling pathways involved in tumor progression and immune response. Immunotherapeutics that are efficacious in other cancer types have unfortunately not enjoyed the same success in glioblastoma, illustrating the challenging and complex nature of this disease and demonstrating the need for development of multimodal treatment regimens utilizing the synergistic qualities of immune-mediated therapies.
\end{abstract}

Keywords Glioblastoma $\cdot$ Immunotherapy $\cdot$ Cancer vaccine $\cdot$ CAR-T $\cdot$ Oncolytic virus $\cdot$ Checkpoint inhibitor

\section{Introduction}

Glioblastoma (GBM) is the most common malignant primary brain tumor, affecting approximately 3 out of 100,000 individuals in the USA [1]. Despite an aggressive standard of care

Abigail L. Mende and Jessica D. Schulte contributed equally to this work. This article is part of the Topical Collection on Neuro-oncology

Hideho Okada

hideho.okada@ucsf.edu

Jennifer L. Clarke

jennifer.clarke@ucsf.edu

Abigail L. Mende

abigail.mende@ucsf.edu

Jessica D. Schulte

jessica.schulte@ucsf.edu

1 Department of Neurological Surgery, University of California, Diller Family Cancer Research Building HD 472, Box 520, 1450 3rd Street San Francisco, Helen, CA 94158, USA regimen of maximal surgical resection followed by combination radiation and alkylating chemotherapy, prognosis remains poor with a $100 \%$ recurrence rate and a median overall survival (mOS) of approximately 20 months [2]. Interest in immunotherapy as an alternative approach has rapidly

2 Department of Neurology, University of California, San Francisco, CA, USA

3 The Parker Institute for Cancer Immunotherapy, Diller Family Cancer Research Building HD 472, Box 520, 1450 3rd Street San Francisco, Helen, CA 94158, USA

4 Cancer Immunotherapy Program, University of California, San Francisco, CA, USA

5 Department of Clinical Neurology and Neurological Surgery, University of California San Francisco, Box 0372, 400 Parnassus Avenue, A895F, San Francisco, CA 94143-0372, USA 
amplified in recent years, following the success of immune checkpoint inhibitors (ICIs) as well as oncolytic viral (OV) therapies in melanoma and other cancers [3-5]. In GBM, however, immune-based therapies have not enjoyed the same success, as demonstrated by the disappointing outcomes of recent randomized, advanced phase clinical trials $[6,7,8 \bullet]$. This review will discuss the current status of immunotherapy for GBM, covering inherent neuroanatomical and immunosuppressive challenges in GBM, as well as ongoing research including cell-based therapy, ICIs, vaccines, and viral therapy.

\section{Neuroanatomical Barriers of Immunotherapy}

The central nervous system (CNS) has long been believed to be an immune-privileged environment. However, recent liveimaging studies revealed a CNS lymphatic system with activated $\mathrm{T}$ cells crossing the blood-brain barrier (BBB), thus giving rise to new questions about the interaction of the CNS with the peripheral immune system [9-11].

While evidence of CNS interaction with the immune system has been noted, three primary barriers deter entry of immune cells into the CNS: the blood-leptomeningeal barrier at the superficial surface, the BBB in the deep parenchymapenetrating capillaries, and the choroid plexus epithelium (Fig. 1) [12••]. On the superficial surface of the brain, the pial meningeal layer coats arteries as they penetrate the brain surface, but does not coat veins exiting the parenchyma. A second layer of protection is provided by the glia limitans, composed of astrocyte foot processes, which re-enforces the basement membrane of arteries and veins as well as the superficial parenchyma itself. Low-molecular-weight molecules and fluid can pass through the glia limitans, but there is only limited exchange of $\mathrm{T}$ cells at this blood-leptomeningeal barrier [13-16]. Deeper in the brain, the BBB restricts the flow of systemic immune cells into the parenchyma. It is formed by specialized endothelial cells with tight junctions, the endothelial basement membrane enforced by pericytes, and the glia limitans. In the post-capillary venules, the endothelial basement membrane is separated from the glia limitans, creating a perivascular space in which immune cells may circulate for potential access to CNS antigens and entry into the CNS. Finally, the choroid plexus epithelium regulates passage of immune cells and solutes into the cerebrospinal fluid (CSF) through specialized tight junctions and efflux pumps [12••].

\section{Impaired Antigen Presentation Conceals Immune System Awareness of GBM}

Antigen-presenting cells (APCs) have four routes from the CNS to reach lymph nodes where the immune response can be initiated. To reach deep cervical lymph nodes, CSF can either drain through the arachnoid villi to central venous sinuses or drain from the subarachnoid space to the lymphatics through the cribriform plate $[10,17]$. CSF can also drain through dural lymphatic vessels in the skull base and through the perineurium of cranial and spinal nerve roots $[9,18]$. These subarachnoid and dural lymphatic pathways allow some immune cell trafficking near the brain surface. By comparison, surveillance immune cells have limited access to the CNS parenchyma except in the post-capillary venules as described above. Interstitial fluid (ISF) flows though the basement membrane of arteries and capillaries, and this narrow pathway limits trafficking of large molecules as well as immune cells [19]. CSF and ISF exchange to a small degree; studies show low-molecular-weight tracers injected into the CSF enter the ISF through aquaporin-4 channels in the astrocyte end feet of the glia limitans [14, 20]. However, age-related protein deposition into blood vessel walls can limit ISF exchange over time $[19,21]$. These forces collectively result in a more immune-privileged environment in the deep parenchyma where GBM often arises. Although the BBB may be partially disrupted in higher grade gliomas, there often remains a significant population of diffusely infiltrative tumor cells deep in the parenchyma that have an intact BBB and therefore may not be as readily accessed by circulating immune cells [22, 23].

The issue of restricted immune cell access is further compounded by the limited habitation of $\mathrm{B}$ and $\mathrm{T}$ cells in normal parenchyma, although CD4+ and CD8+ T cells can become activated by specific antigen either locally or systemically and then traverse the BBB, even in the absence of neuroinflammation [24, 25]. Entry of activated $T$ cells into the brain parenchyma can occur through the dynamic interaction of adhesion and signaling molecules expressed by immune cells and endothelial cells lining post-capillary venules in parenchymal perivascular spaces [26•].

\section{Tumor Heterogeneity Limits Degree and Durability of Response to Therapy}

Tumor heterogeneity in GBM seriously undermines robust and durable responses to therapeutic interventions, driving poor survival outcomes. In addition to significant genetic diversity between different GBMs, there is substantial subclonal diversity within individual tumors, as defined by genetic and epigenetic profiling [27-31]. Furthermore, single-cell transcriptional profiling has demonstrated that individual GBM cells have temporal variation in gene expression regulating cellular function and the balance between stem-like and differentiation states [32]. In addition, exposure to chemotherapy and radiation, as well as microenvironmental differences in 


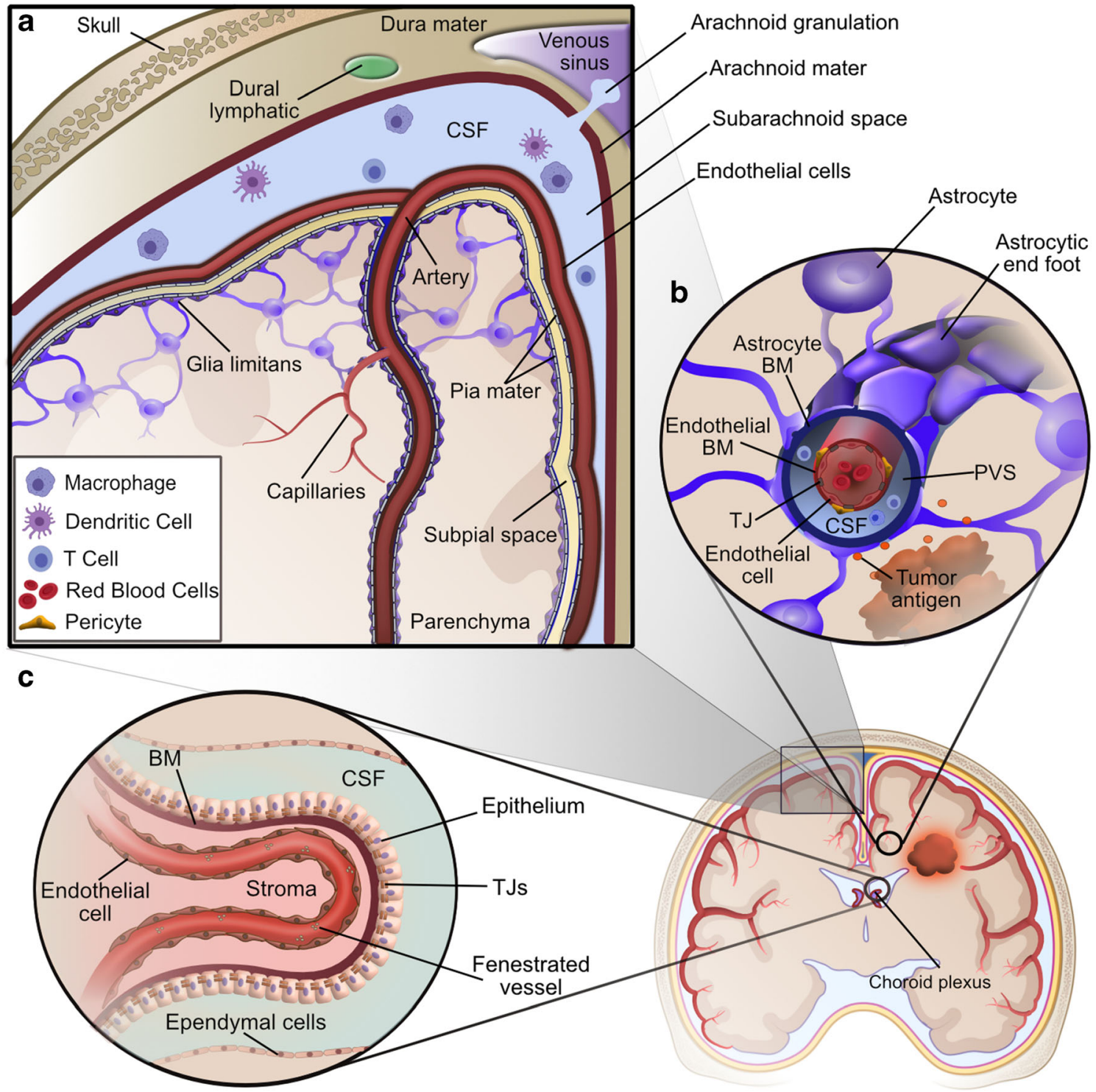

Fig. 1 Central nervous system barriers to immunological communication. a The blood leptomeningeal barrier at the surface of the brain is composed of the glia limitans and pia mater covering the arteries, while veins exiting the parenchyma are protected only by the glia limitans. Additionally, the subarachnoid space is partitioned from the dural lymphatic system by the arachnoid mater, with the exception of arachnoid granulations allowing regulated drainage into the venous sinus. b The blood brain barrier deep in the brain parenchyma is composed of endothelial cells tightly linked together by tight junctions (TJ) and is further enforced by an endothelial basement membrane (BM).

oxygen and other nutrients, can selectively pressure the expansion of certain subclones, or induce hypermutation [33].

Common genetic mutations in adult GBM frequently targeted by immunotherapy include the epidermal growth factor receptor variant III (EGFRvIII) mutation and the isocitrate dehydrogenase (IDH1) R132H mutation, while targets in pediatric gliomas include a conserved missense mutation in histone $\mathrm{H} 3$ from lysine $(\mathrm{K})$
In the case of the post-capillary venule shown here, the endothelial BM is separated from the lining of glia limitans formed by astrocytic foot processes and the astrocytic BM, leaving a small perivascular space (PVS) filled with cerebral spinal fluid (CSF), in which immune cells can circulate and potentially interact with CNS antigens. $\mathbf{c}$ The choroid plexus tightly regulates parenchymal solute exchange with the CSF and inner stroma using a layer of epithelial cells, the epithelium, linked by tight junctions as well as a layer of ependymal cells (Adapted from Engelhardt, B et al. 2019) Created with BioRender.com and Affinity Designer software

to methionine (M) at position 27 (H3 K27M mutation) [34-36]. While most tumor-specific antigens are expressed heterogeneously within tumor, the H3 K27M mutation is homogeneously distributed throughout the entire tumor [37, 38], suggesting that this may be a truncal mutation and less likely to lead to antigen loss-mediated escape of the tumor when targeted therapeutically. 


\section{Immunosuppression in Glioblastoma}

Glioblastoma can impair both local CNS and systemic immune system functions, by hijacking major immunogenic signaling pathways and altering cellular immunity inside and outside the brain. In addition, there are immunosuppressive side effects of chemotherapy and radiation.

\section{The Impact of Glioblastoma on Immune Cell Composition and Functionality}

GBM alters physical and functional aspects of the brain immune system through production of immunosuppressive factors and modulation of cell surface receptors and immune cell subsets [39]. GBM induces systemic sequestration of naïve T cells in the bone marrow due to downregulation of sphingosine 1-phosphate receptor, contributing to low levels of effector $\mathrm{T}$ cells systemically and in the tumor micro-environment (TME) [40•]. The scarcity of effector $\mathrm{T}$ cells in the tumor is compounded by enrichment of regulatory $\mathrm{T}$ cells $\left(\mathrm{T}_{\text {reg }}\right)$, a subpopulation of $\mathrm{CD} 4+\mathrm{T}$ cells that suppress effector $\mathrm{T}$ cells through cytotoxic $\mathrm{T}$ lymphocyte-associated protein 4 (CTLA4) signaling and secretion of cytokines TGF- $\beta$ and interleukin-10 [41, 42]. Additionally, the immune cell composition of the GBM TME is characterized by a large population of macrophage and myeloid-derived cells, as compared to the meager presence of lymphocytes [43]. Tumor-associated macrophages (TAMs) support the progression of GBM through promoting angiogenesis and suppressing the adaptive immune response [44]. Collectively, solid tumor cancers, principally GBMs, that bear enrichment of macrophages are associated with shorter survival compared to tumors without such enrichment [43]. Myeloid-derived suppressor cells (MDSCs) further dampen the adaptive immune response by suppressing the proliferation and functionality of tumor-infiltrating $\mathrm{T}$ cells through the production of anti-inflammatory cytokines and $\mathrm{T}$ cell suppressive compounds as well as upregulation of the transmembrane protein, programmed death-ligand 1 (PD-L1) [45-47]. In addition to these complex cellular mechanisms, GBM-associated hypoxia results in over-production of angiogenic factors including vascular endothelial growth factor (VEGF) and hypoxia-inducible factor1-alpha (HIF-1a), creating an irregular vascular network that results in limited access to nutrients, immune cells, and therapeutic treatments [48].

\section{Modulation of Centralized Signaling Pathways by Glioblastoma Promotes Immunosuppression}

The ability of GBM to escape immune surveillance through deregulated signaling pathways enhances its ability to overcome many therapeutic strategies, including immunotherapies. For example, TGF- $\beta$, a major GBM-secreted factor, contributes to immunosuppression, angiogenesis, and maintenance of the glioma progenitor population through its involvement in multiple signaling pathways [49]. In addition, both GBM tumor cells and infiltrating immune cells induce constitutive activation of signal transducer and activator of transcription 3 (STAT3), which drives multiple prooncogenic pathways and dampens the anti-tumor immune response through recruitment and expansion of $\mathrm{T}_{\text {reg }}$ cells and MDSCs, induction of T cell tolerance through STAT3 hyperactivation in APCs, and regulation of immunosuppressive cytokines [50]. However, while effective in preclinical settings of a variety of different cancers including GBM, inhibition of STAT3 fails to provide a viable therapeutic option as STAT3 regulates many other necessary biological processes, and inhibition results in unintended side effects such as thrombocytopenia [51]. In addition, the fibrinogen-like protein 2 (FGL2) pathway promotes immunosuppression through increasing expression of programmed cell death-1 (PD-1) on T cells and by expanding populations of TAMs, MDSCs, and $\mathrm{T}_{\text {reg }}$ cells in the TME [52].

\section{Suppression of the Immune Response by Standard Therapy and Corticosteroids}

Patients with high-grade glioma that undergo standard-ofcare (SOC) treatment with concurrent radiation and alkylating temozolomide (TMZ) may demonstrate CD4+ lymphopenia, which increases the patient's risk for infections including Pneumocystis jiroveci pneumonia (PJP, formally known as PCP) [53]. In addition, patients are also often treated with dexamethasone, a synthetic glucocorticoid, for peri-operative control of intracerebral edema and consequent neurological symptoms (e.g., headaches, confusion, weakness, other focal neurological deficits, and seizures). However, dexamethasone and other glucocorticoids significantly dampen the overall immune response and can reduce therapeutic benefit of immunotherapies, resulting in consensus recommendations that their use be minimized prior to and during immunotherapy trials [54-56]. For example, it was recently reported that use of dexamethasone hampered vaccine-reactive $\mathrm{T}$ cell responses during neoantigen vaccine priming in patients with newly diagnosed malignant glioma $[56,57]$.

\section{Recent Advances in Immunotherapy}

Over the past few decades, a multitude of immunotherapeutic strategies have attempted to eradicate and overcome GBM, including CAR-T cell, vaccine, immune checkpoint inhibitors (ICI), and OV therapies, discussed in detail below and summarized in Fig. 2. 


\section{Cell-Based Therapy: Chimeric Antigen Receptor T Cell Therapy}

The purpose of cell-based therapy is to enhance the anti-tumor activity of patient-derived $\mathrm{T}$ cells by engineering them to express either a chimeric antigen receptor (CAR) or a $\mathrm{T}$ cell receptor (TCR) targeting specific tumor antigens. However, this section will focus primarily on CAR-T cell therapy [58]. Unlike CAR-T cells, TCR-modified T cells rely on major histocompatibility class (MHC) peptide presentation, which GBM can suppress, thereby evading MHC-restricted $\mathrm{T}$ cell recognition and rendering TCR-modified $\mathrm{T}$ cells incapable of recognizing tumor-associated antigens (TAAs) [59]. To circumvent this issue, CAR-T cells are engineered to express a CAR, composed of a single-chain variable fragment specific to the target, a $\mathrm{T}$ cell activation domain $(\mathrm{CD} 3 \zeta)$, and one or more co-stimulatory domains (such as 4-1BB, CD28, OX40), which redirects T cell specificity to an extracellular TAA [59, 60].

In a recent phase I study, autologous CAR-transduced T cells targeting the constitutively active $E G F R$ variant EGFRvIII, which is present in $24-67 \%$ of GBM cases, were intravenously administered to 10 recurrent GBM patients. The mOS was 8.25 months, and 4 patients who underwent reresection within 14 days of treatment demonstrated infiltration of CAR-T cells and increased activated lymphocytes within the resected tumor [61]. However, another phase I trial, which utilized a third-generation CAR construct of EGFRvIII, did not show therapeutic benefit [62]. The glioma-associated antigen interleukin-13 receptor alpha 2 (IL13R $\alpha 2)$, found in

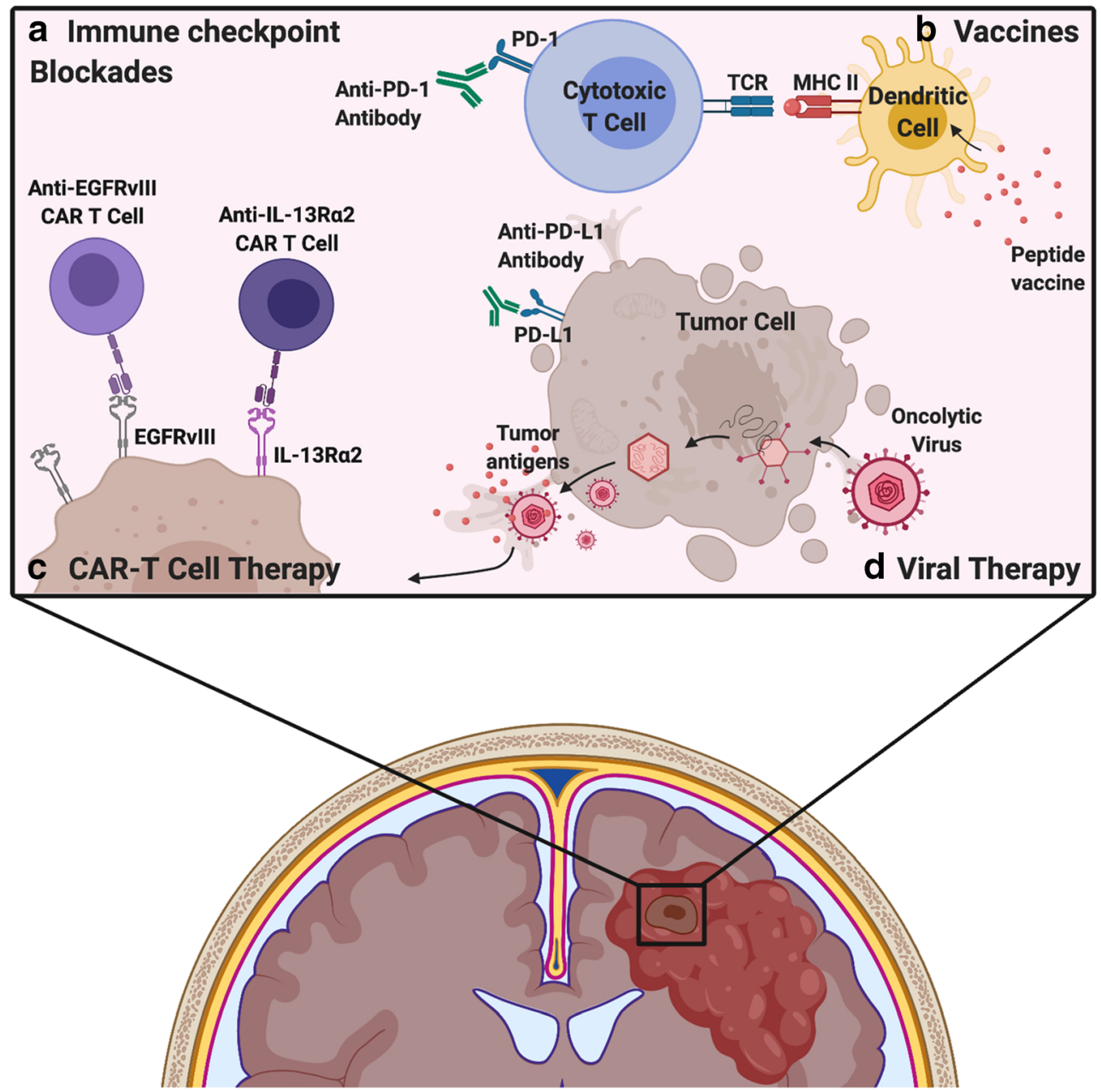

Fig. 2 Immunotherapeutic strategies for treatment of glioblastoma. a Immune checkpoint receptor/ligands such as PD-1 expressed on T cells and PD-L1 expressed on tissue cells downregulate the adaptive immune response in normal tissues. Tumors may express PD-L1 as well, thus inhibiting $\mathrm{T}$ cell activation in tumors. Immune checkpoint inhibitors are antibodies that block receptor-ligand interactions, such as between PD-1 and PD-L1, thus inhibiting the immunosuppressive effects of this interaction. b Vaccines introduce GBM-specific antigens to native APCs including dendritic cells and rely on MHC-dependent presentation to T cells to stimulate a GBM-targeted immune response. $\mathbf{c}$ CAR-T cell therapy uses autologous $\mathrm{T}$ cells, which are genetically modified to target GBM-specific surface antigens, such as EGFRvIII and IL-13R $\alpha 2$. Unlike vaccines, CAR-T cells do not rely on MHCdependent antigen presentation. d Viral therapy encompasses the use of oncolytic viruses and retroviruses to either initiate tumor cell lysis and release of tumor antigen or to integrate therapeutic transgenes for expression by the tumor cell 
approximately $58 \%$ of adult GBM cases and $83 \%$ of pediatric brain tumors, has also been targeted by CAR-T cells in the clinical setting [63, 64]. Preliminary results for an ongoing phase I trial with IL-13 $\alpha 2$ CAR-T cells demonstrated radiographic response of both intracranial and metastatic spinal tumors in one patient for 7.5 months $[63,65]$. Interestingly, initial intracavitary CAR-T cell delivery resulted in localized tumor control with no effect on distant tumor sites, but there was significant regression of disseminated disease after adjunctive intraventricular delivery [65]. Other CAR-T clinical trials targeting single antigens in GBM have been largely unsuccessful; however, novel targets are currently under clinical investigation (Table 1).

While hematologic cancers have been successfully treated with CAR-T cell therapy, its efficacy against CNS and other solid tumors has been limited by a host of barriers including heterogeneously expressed tumor antigens, limited persistence and homing to distant tumor sites, and TME-mediated immunosuppression [88]. To address GBM heterogeneity, there are several exploratory CAR-T systems in development that target multiple antigens, either in parallel or in tandem [89-93]. Additionally, improving CAR-T persistence within the CNS requires refinement of delivery, timing, and frequency and has been limited by incomplete understanding of CAR$\mathrm{T}$ cell viability after CNS entry. In a phase I clinical trial with EGFRvIII CAR-T cells delivered through a single intravenous infusion, peak peripheral expansion of CAR-Ts was noted 3-10 days after infusion, and detected up to 30 days after infusion, as defined by flow cytometry of peripheral blood samples [61]. Although this study looked at in situ tumor engraftment of CAR-T cells in tumors that were later resected, sample size was small $(n=7)$ and engraftment variable, so it is difficult to determine if tumor engraftment is related to amount and duration of CAR-T cells in the periphery or other factors [61]. Intratumoral, intracavitary, and/or intraventricular delivery may further improve durability of response. In comparison to intravenous therapy, preclinical studies have suggested that intraventricular (intrathecal) delivery may lead to faster tumor infiltration, increased penetration into the tumor core, and longer persistence within the tumor [94, 95]. However, preliminary evidence in one patient who received intrathecally delivered CAR-Ts targeting IL13R $\alpha 2$ showed that CAR-T cells may persist in the cerebrospinal fluid for only 7 days, although this study did not look at CAR-T infiltration into the tumor itself [65]. Delivery issues including method and frequency need further investigation and would benefit from improved, non-invasive monitoring techniques, as discussed later.

\section{Immune Checkpoint Inhibitors}

Despite success in other cancers, ICI blockade of PD-1/PD-L1 and CTLA-4 has been grossly unsuccessful thus far in GBM.
A phase III trial comparing the PD-1 inhibitor nivolumab to VEGF-A inhibitor bevacizumab showed no improvement in survival in patients with recurrent GBM (CheckMate-143) [8•]. The Checkmate-498 trial, comparing nivolumab plus radiation (RT) versus standard-of-care temozolomide plus RT in patients with newly diagnosed GBM without MGMT promoter methylation (a poor prognostic factor), was stopped after nivolumab with radiation did not show improved survival compared to temozolomide with radiation (NCT02617589, publication pending). There is a complementary ongoing trial in patients with newly diagnosed $M G M T$ promoter methylated GBM (CheckMate-548, NCT02667587). Preliminary results have shown that there is no improvement in progression-free survival (PFS) with the addition of nivolumab to temozolomide and RT, but final results regarding OS are pending. Several ongoing trials are also exploring the combination of nivolumab with the CTLA-4 inhibitor, ipilimumab (Table 1).

Interestingly, while checkpoint inhibition has been mostly ineffective in GBM, there has been some efficacy demonstrated in brain metastases (BMs) from systemic cancers including melanoma and non-small cell lung cancer [96-98]. The discrepancy in efficacy of ICI therapy between BMs and GBM may be partially explained by the variation in immune cell phenotype, function, and spatial organization of each tumor type's respective TME [99]. Two recent, comprehensive analyses of the TME in both primary and metastatic brain malignancies found that BMs, especially melanomas, were characterized by higher proportions of lymphocytes, including CD8+ T cells, unlike gliomas, which instead exhibited an abundance of tissue-resident microglia and myeloid cells $[99,100 \bullet \cdot$. The efficacy of ICIs in metastases may also relate to neuroanatomical differences; metastases have BBB remodeling that may allow for more efficient immune cell intravasation [101, 102]. In addition, metastases are often well circumscribed, and a higher percent volume of each metastasis has BBB disruption, compared to diffusely infiltrating astrocytomas that have large areas of tumor with an intact BBB [103].

Other factors contributing to the failure of ICIs in GBM may include decreased passage through the BBB of ICI and activated $\mathrm{T}$ cells, as well as low expression of neoantigens by GBM compared to other systemic tumors [104]. As there are few tumor-infiltrating lymphocytes (TILs) in GBM [105], maximal efficacy of checkpoint inhibitors may require initial peripheral activation of circulating $T$ cells [106 ${ }^{\bullet}$. There is an ongoing study to evaluate if there is utility in combining intravenous/intrathecal delivery of PD-1 inhibitors in brain metastases of melanoma (NCT03025256), but no such trial has yet been undertaken in primary brain tumors. Compounding the lack of access of CTLA4-expressing APCs and PD-1-expressing T cells to the CNS, not all GBMs express PD-L1, and those that do show PD-L1 expression in fewer than $5 \%$ of cells [107-110]. In addition, the 


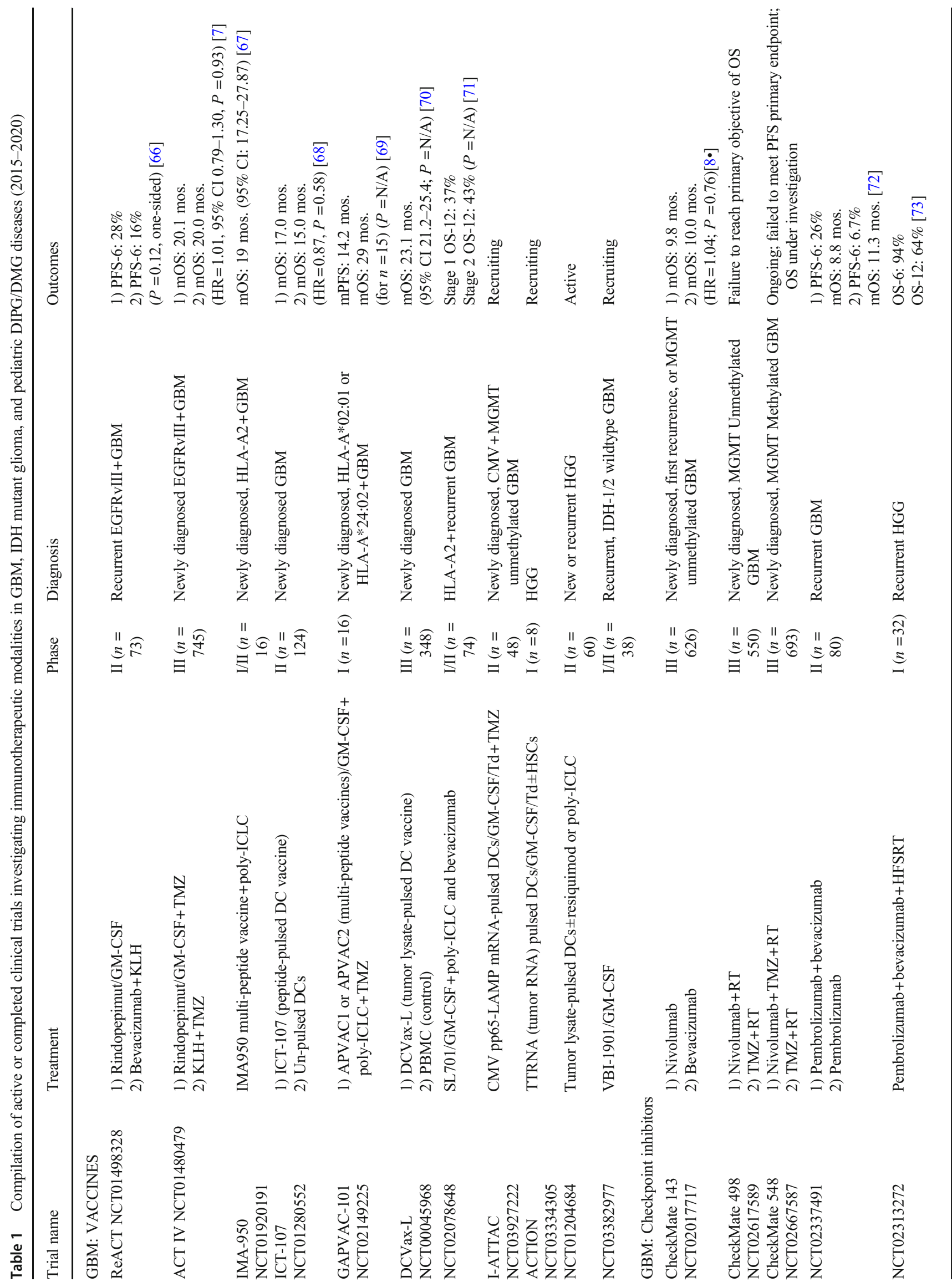




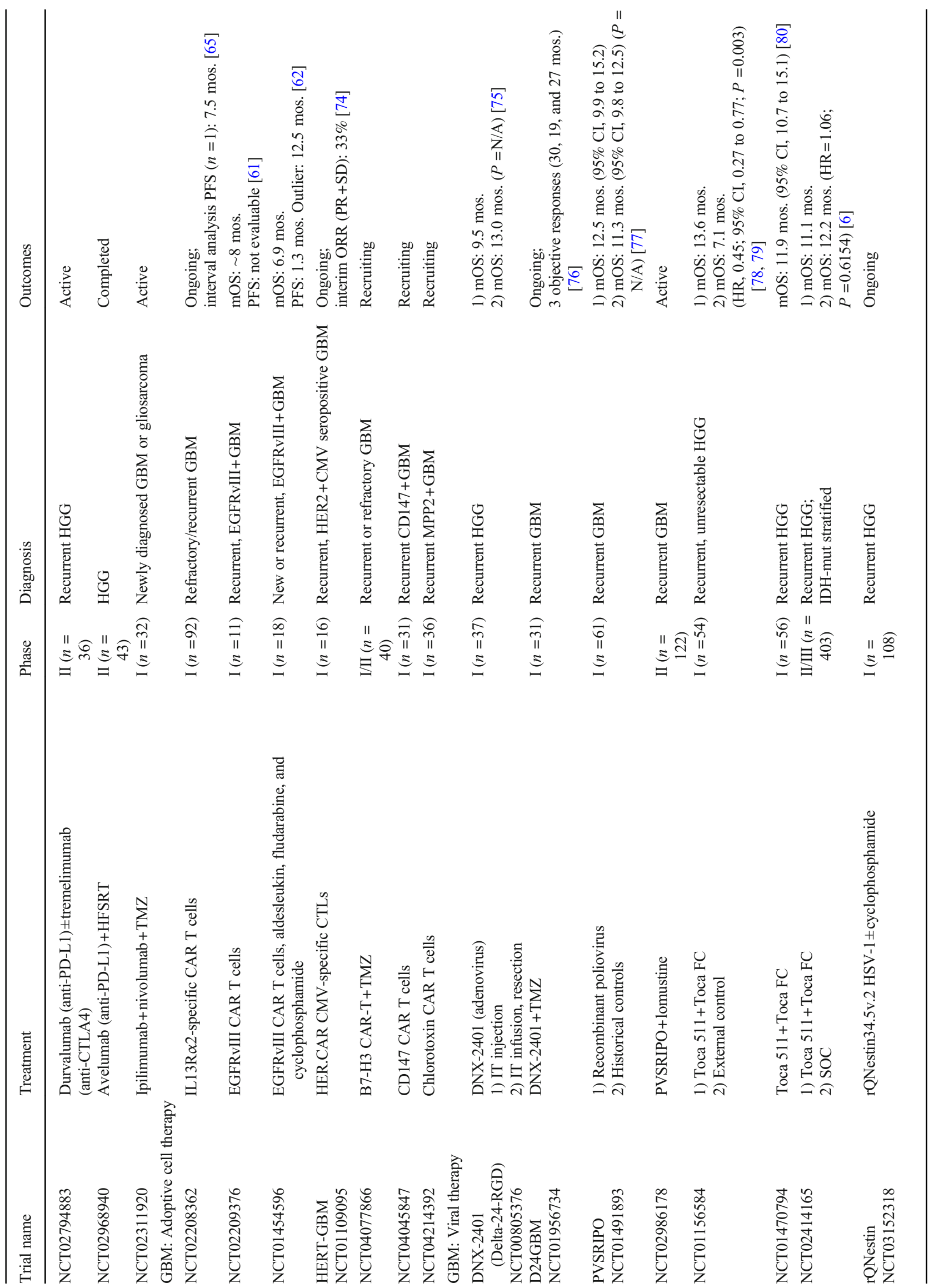




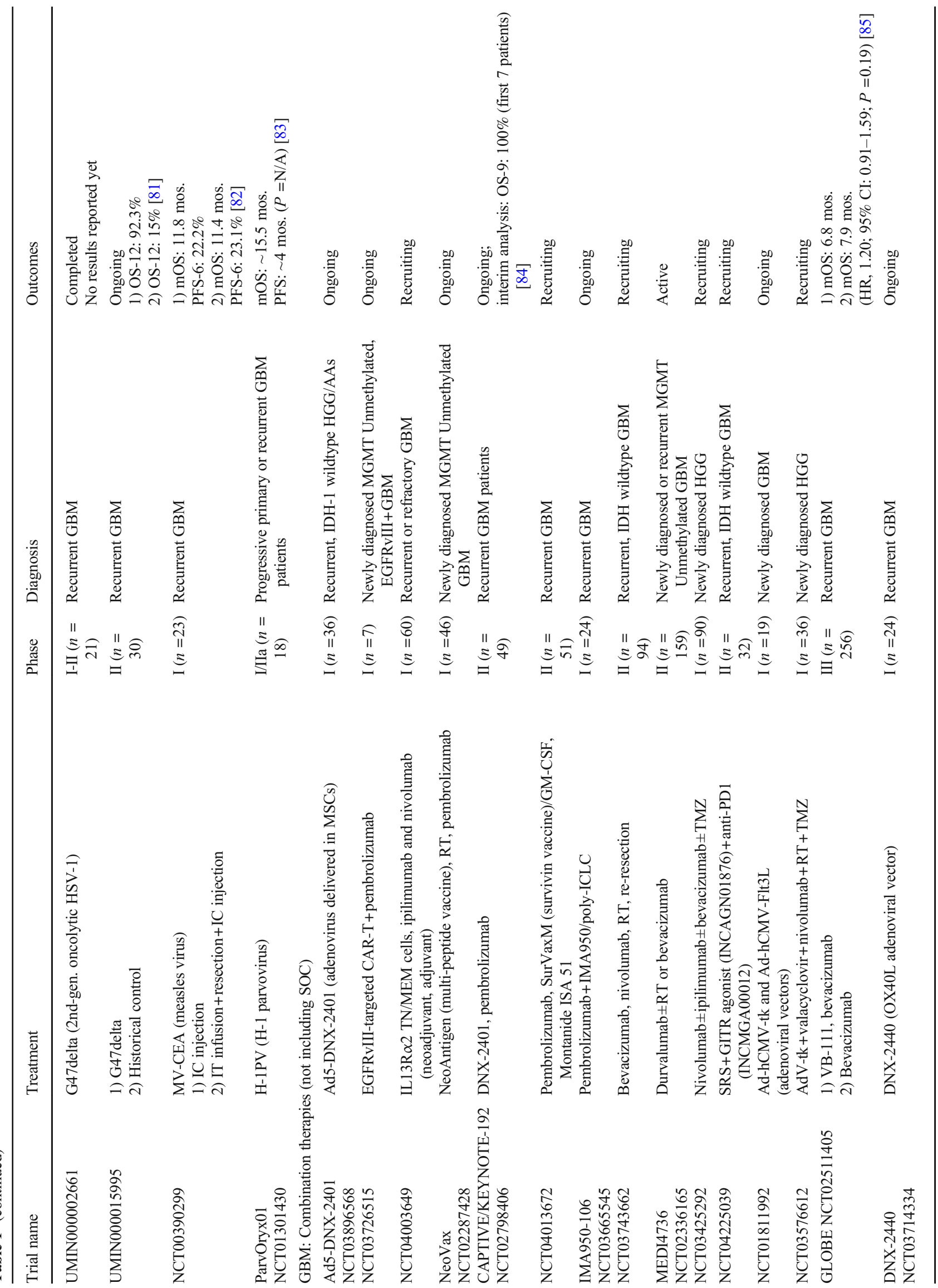




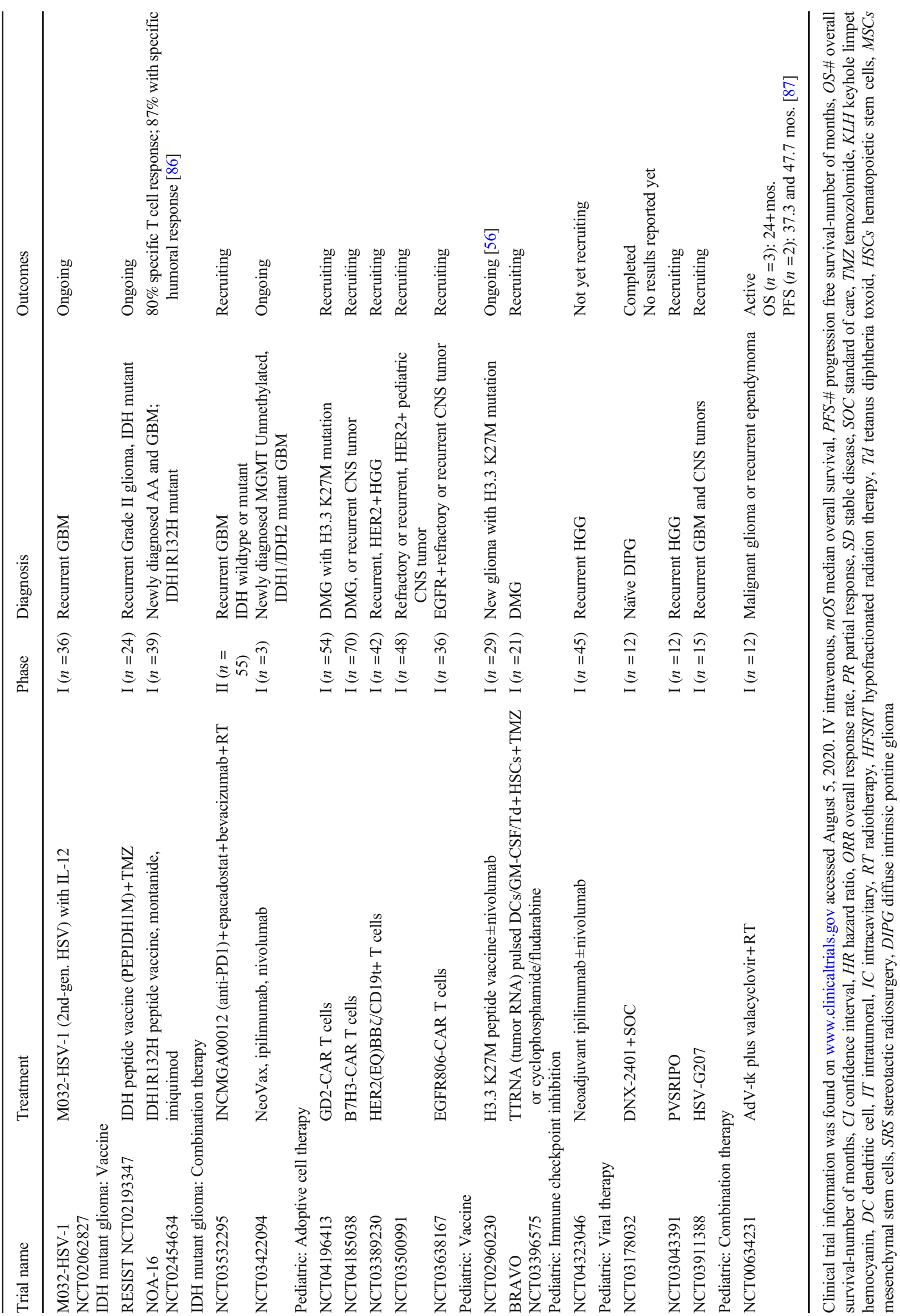


tumor mutational burden and neoantigen expression are lower compared to systemic cancers [107-110]. Furthermore, patients with GBM often have impaired systemic immunity, limiting the potential response to checkpoint inhibition [40•]. With ICI exposure, there may be compensatory upregulation of the tumor-driven immunosuppressive pathways, including upregulation of other checkpoint pathway ligands that could cause $\mathrm{T}$ cell exhaustion. Finally, there may be some relevance to ICI timing, as a recent small trial demonstrated improved survival in GBM with treatment with the anti-PD-1 antibody, pembrolizumab, prior to surgery, suggesting possible utility to immune system priming prior to antigen exposure during surgery [111•].

\section{Vaccine Therapy}

Given the immunologically "cold" environment of GBM, efforts have been made to enhance the adaptive arm of the immune system to target GBM cells through cell-mediated immunity [112]. Three peptide or dendritic cell (DC)-based vaccines recently reached phase III clinical trial testing. In the phase III trial Act IV, rindopepimut, an immunogenic peptide vaccine targeting EGFRvIII, elicited a strong humoral response but conferred no significant improvement in PFS or mOS [7]. Durability of response may have been hampered by acquired loss of EGFRvIII expression, illustrating one of the greatest shortcomings of single-antigen vaccines [7]. On the other hand, a multi-peptide DC vaccine, ICT-107, targeting six GBM-specific HLA-A1 and A2 antigens was tested in a randomized phase II trial and prolonged patient PFS to 11.4 months, a significant increase compared to the control group's PFS of 10.1 months (HR $=0.64, p=0.033$ ) [68]. ICT107 was most effective in extending the mOS and PFS in HLA-A2+ patients or patients with $M G M T$-methylated GBM [68]. A follow-up phase III trial testing ICT-107 was attempted, but was discontinued due to inadequate funding. The third vaccine to reach phase III testing is DCVax-L, derived by educating autologous DCs with whole tumor lysate extracted from individual patient resections. The interim results of the placebo-controlled phase III DCVax-L trial showed an mOS of 23.1 months; however, the analysis included all patients and was not broken down by treatment group [69, 70].

Other single- and multi-antigen vaccines are under investigation in early phase trials, including (IDH1) R132H and H3.3K27M peptide vaccines. The (IDH1) R132H peptide vaccine targets a frequently occurring mutation in the IDH1 gene found primarily in lower grade gliomas, which is responsible for aberrant neural signaling and glioma progression [35]. In the phase I NOA-16 trial, this vaccine was administered with SOC in newly diagnosed patients with (IDH1) R132H-positive WHO Grade III and IV astrocytomas. Preliminary results demonstrated induction of a humoral immune response with a reasonable toxicity profile [86]. In a recent multicenter pilot study, vaccine targeting $\mathrm{H} 3.3 \mathrm{~K} 27 \mathrm{M}$, along with Toll-like receptor 3 agonist, polyinosinicpolycytidylic acid stabilized with polylysine and carboxymethylcellulose (poly-ICLC), was administered to HLAA02.201+ pediatric patients with $\mathrm{H} 3.3 \mathrm{~K} 27 \mathrm{M}+$ diffuse midline glioma (DMG). A subset of patients $(n=18)$ were selected for available multi-timepoint blood draws and $39 \%$ exhibited an expansion of $\mathrm{H} 3.3 \mathrm{~K} 27 \mathrm{M}$-reactive $\mathrm{CD}^{+} \mathrm{T}$ cells (mOS 16.3 months) and showed significantly prolonged OS compared to tumors who failed to demonstrate a $\mathrm{T}$ cell response (mOS 9.9 months) [56]. Furthermore, dexamethasone administration is inversely associated with H3.3K27M-reactive $\mathrm{CD}^{+} \mathrm{T}$ cell responses [56].

Multi-peptide vaccines are designed to elicit a strong $\mathrm{T}$ cell response to multiple tumor antigens. For example, IMA-950 (multi-peptide vaccine composed of 9 MHC class I and 2 MHC class II peptides), with poly-ICLC, was recently tested in a phase I clinical trial and resulted in patients developing tumor peptide-specific CD4+ and CD8+ T cell responses, with the IMA-950 antigens remaining stably expressed on the tumor throughout the course of the disease [67]. Another multi-peptide vaccine was tested in the GAPVAC-101 trial, in which personalized cocktails of pre-manufactured peptide vaccines utilized non-mutated GBM antigens (APVAC1) and neoepitopes (APVAC2) to elicit an immunological response. This trial demonstrated sustained memory CD8+ T cell responses induced by APVAC1, while a $\mathrm{T}_{\mathrm{H}} 1 \mathrm{CD} 4+\mathrm{T}$ cell response was elicited by APVAC2 [113]. Another recent phase I/Ib study tested the efficacy of a personalized neoantigen vaccine in newly diagnosed GBM patients and found the vaccination promoted neoantigen-specific $\mathrm{CD} 4^{+}$ and $\mathrm{CD}^{+} \mathrm{T}$ cell responses and additionally increased the number of tumor-infiltrating T cells [57].

\section{Viral Therapy}

Aberrant cellular pathways in GBM provide a favorable environment for specially modified viruses to selectively replicate [114]. Following successful replication within target tumor cells, oncolytic viruses (OVs) elicit lytic cell death, provoking a strong inflammatory response followed by a tumor-targeted immune response, initiated by the liberation of damageassociated molecular patterns (DAMPs) and TAAs from tumor cells [115, 116]. A variety of viruses have been reengineered to target GBM and have been critically reviewed by Chiocca et al. (2019) [117••].

Adenoviruses can be readily manipulated to drive cell death, facilitate an immunogenic anti-tumor response, or carry therapeutic transgenes [118]. For example, conditionally replicative adenoviruses have been modified to selectively replicate in tumor cells with aberrant $\mathrm{p} 16 / \mathrm{Rb} / \mathrm{E} 2 \mathrm{~F}$ signaling (which controls the activity of the retinoblastoma tumor suppressor 
protein $(\mathrm{Rb})$, a regulator of the E2F transcription factor) [119]. DNX-2401 (previously delta-24-RGD) selectively replicates within brain tumor stem cells with an abnormal p16INK $4 / \mathrm{Rb}$ pathway [120]. Recently, a phase I clinical trial demonstrated that replication of DNX-2401 in recurrent GBM tumors facilitated tumor cell death and some immunogenic cell death by infiltrating CD8+ T cells and $\mathrm{T}_{\mathrm{H}}$ cells, lengthening mOS to 13.0 months [75]. Another phase I trial in newly diagnosed GBM seeks to capitalize on putative synergy between DNX2401 and temozolomide, improving tumor recognition by CD8+ T cells [121, 122]. Interim results reported several objective radiological responses up to 30 months [76]. G47delta, a conditionally replicating, double mutant derivative of herpes simplex virus-1 (HSV-1), is another oncolytic virus undergoing current investigation. In a phase II trial in recurrent/ residual glioblastoma, G47delta was injected intracranially in combination with adjuvant TMZ, resulting in an influx of lymphocytes, and interim results have reported a 1-year survival of $92.3 \%$ [123].

Unlike OVs, replicating retroviruses (RRVs) are non-lytic, require an actively dividing host cell to support viral replication, and can act as selective carriers of exogenous procytotoxic transgenes [124]. Toca 511 (vocimagene amiretrorepvec) is an RRV carrying a modified yeastderived cytosine deaminase gene (CD) that integrates into the tumor cell genome and converts systemically delivered pro-drug, 5-fluorocytosine (5-FC) into cytotoxic 5fluorouracil (5-FU) [124]. Despite promising phase I results, the phase II/III trial failed to improve OS as compared to a SOC cohort, with mOS of 11.1 and 12.2 months, respectively, leading to premature termination [6]. It should be noted that certain factors predicted improved survival, namely diagnosis of anaplastic astrocytoma, presence of IDH1 R132H mutation, and second disease recurrence.

\section{Moving Forward}

Thus far, immunotherapy has had minimal impact on the survival of GBM patients, challenged by limitations with antigen presentation, immune cell trafficking into the CNS, tumor infiltration, and immunosuppression from the tumor and its treatments. Additionally, accurate assessment of the efficacy of immunological therapies is challenged by the limited functionality of non-invasive monitoring tools, resulting in cases of premature treatment discontinuation and a limited understanding of treatment impact.

\section{Overcoming Adaptive Immune Resistance and Immune Escape}

Novel therapies need to address mechanisms of immune escape, including $\mathrm{T}$ cell exhaustion and adaptive resistance
[125]. One strategy addressing T cell exhaustion includes co-administration of a glycogen synthase kinase 3 (GSK3) inhibitor with CAR-T cell therapy as there is some evidence that this may reduce CAR-T exhaustion and help establish an effector memory T cell population [126]. Due to some evidence that the PD-L1 ligand may be upregulated after CAR-T therapy [61, 127], one ongoing trial has incorporated checkpoint inhibition in conjunction with CAR-T (Table 1). Another similar strategy involved modification of Delta2401 (previously delta-24-RGD) adenovirus to deliver the gene for the OX40 ligand T cell stimulatory gene to glioma tumor cells. An exploratory study administered this modified virus (Delta-24-RGDOX or DNX2440) with a PD-L1 inhibitor and noted an increase in infiltrative $\mathrm{T}$ cells in vivo in a preclinical tumor model, leading to the initiation of a phase I clinical trial (see Table 1) [128]. Finally, anti-CTLA-4 (ipilimumab) and anti-PD1 (pembrolizumab) have been used in clinical trials and are currently undergoing investigation in combination with a vaccine therapy (Table 1).

Advances in gene therapy offer a multimodal approach to targeting GBM. In an ongoing phase I trial, patients were given intratumoral injections of an adenovirus encoding HSV type I thymidine kinase (Ad-TK), which converts systemically delivered valacyclovir to cytotoxic ganciclovir within infected tumor cells, in addition to a second adenovirus delivering the dendritic cell (DC)-recruiting Fms-like tyrosine kinase 3 ligand (Ad-Flt3L) to transform the tumors into DCattracting hot zones. In mouse xenografts, this gene therapy was combined with a combinatorial PD-1/CTLA-4 blockade, which reduced the MDSC population and enhanced survival [129•].

Other combinatorial approaches have attempted to simultaneously target the lifeblood of the tumor while forcing tumor cells into apoptosis by using VEGF inhibitors and gene therapy. For example, in the phase III randomized GLOBE trial, VEGF inhibitor bevacizumab was combined with the VB-111 adenovirus, which delivers a transgene activating the Fas proapoptotic pathway in tumor endothelial cells; however, this combination did not extend mOS compared to bevacizumab monotherapy (Table 1) [85]. Of note, early phase trials with VB-111 had a median OS of 13.6 months, but VB-111 was administered concurrently with bevacizumab, rather then prior to bevacizumab as was the case in later trials [85]. Other ongoing combinatorial therapies are summarized in Table 1.

\section{Current Diagnostic Shortcomings and Solutions}

Advancement in the use of immunotherapy in GBM will also require improved methods to assess immune response in the tumor. Unfortunately, this assessment currently relies on invasive biopsy, with limited functionality of non-invasive monitoring tools. 
Magnetic resonance imaging (MRI) is limited in its ability to distinguish between tumor, treatment effect, and inflammatory infiltration [130]. The Immune Response Assessment in Neuro-Oncology (iRANO) guidelines for interpreting MRIs while on immunotherapy were released in 2015 [54]. These recommend deferring final interpretation of MRI changes for 3 months, a relatively long period for a disease with mOS of 20-22 months from initial diagnosis and approximately 9 months from recurrence. Other advanced imaging techniques, including MRI with delayed or dynamic susceptibility contrast, dynamic MRI perfusion, arterial spin labeling, diffusor tensor imaging, MR spectroscopy, and position emission tomography (PET), all lack the sensitivity, specificity, and/or resolution to reliably predict which areas of imaging correlate to tumor progression versus immune infiltrate [130]. There has been some effort to label lymphocytes ex vivo with a radionuclide or MRI probe at the cell surface, or to engineer cytolytic CD8+ T cells to express a radionuclide, PET reporter gene, or MRI reporter gene [131]. In other neuroinflammatory conditions including multiple sclerosis (MS) and cerebral infarct, radioisomer C11-PK11195-labeled translocator protein can identify activated astrocytes, microglia, astrocytes, and macrophages imaged using PET [130, 132]. In MS, ultra-small paramagnetic iron oxide nanoparticles have also been used to image infiltrative immune cells where the BBB is intact [133]. These technologies could potentially be extended to immunotherapy in GBM.

\section{Conclusion}

Therapeutic success with immunotherapy in GBM has been challenged by immune surveillance evasion through multiple deregulated signaling pathways, limited antigen presentation, and production of immunosuppressive cytokines and regulatory immune cells. These failures have emphasized that successful treatment of GBM may rely on combination therapies, with cell-based therapies targeting multiple specific antigens and therapies that indiscriminately target a broad population of GBM cells, such as oncolytic viruses. Furthermore, thoughtful design of dosing schedules and delivery methods of cell-based therapies, oncolytic viruses, immune checkpoint inhibitors, and vaccines is essential in affirming their best possible performance when used in the combination therapy setting.

\section{Compliance with Ethical Standards}

Conflict of Interest Abigail L. Mende and Jessica D. Schulte declare no conflict of interest. Hideho Okada has received research funding from Agios Pharmaceuticals, has received compensation for service as a consultant from Bristol-Myers Squibb and Agios Pharmaceuticals, and receives royalties on three issued patents: inventor of H3.3k27M TCR (licensed to Tmunity, Inc.), IL-13Ra2 (345-353:1A9V) peptide (licensed to Stemline, Inc.), and EGFRvIII-CAR (licensed to Novartis). Jennifer L. Clarke has received clinical trial funding from Agios Pharmaceuticals, Merck, and Novartis and has received compensation from Agios Pharmaceuticals for service as a consultant.

Human and Animal Rights and Informed Consent This article does not contain any studies with human or animal subjects performed by any of the authors.

Open Access This article is licensed under a Creative Commons Attribution 4.0 International License, which permits use, sharing, adaptation, distribution and reproduction in any medium or format, as long as you give appropriate credit to the original author(s) and the source, provide a link to the Creative Commons licence, and indicate if changes were made. The images or other third party material in this article are included in the article's Creative Commons licence, unless indicated otherwise in a credit line to the material. If material is not included in the article's Creative Commons licence and your intended use is not permitted by statutory regulation or exceeds the permitted use, you will need to obtain permission directly from the copyright holder. To view a copy of this licence, visit http://creativecommons.org/licenses/by/4.0/.

\section{References}

Papers of particular interest, published recently, have been highlighted as:

- Of importance

•• Of major importance

1. Ostrom QT, Cioffi G, Gittleman H, Patil N, Waite K, Kruchko C, et al. CBTRUS Statistical Report: primary brain and other central nervous system tumors diagnosed in the United States in 20122016. Neuro-Oncology. 2019;21(Suppl 5):v1-v100. https://doi. org/10.1093/neuonc/noz150.

2. Stupp R, Taillibert S, Kanner A, Read W, Steinberg D, Lhermitte $\mathrm{B}$, et al. Effect of tumor-treating fields plus maintenance temozolomide vs maintenance temozolomide alone on survival in patients with glioblastoma: a randomized clinical trial. JAMA. 2017;318(23):2306-16. https://doi.org/10.1001/jama.2017. 18718.

3. Pol J, Kroemer G, Galluzzi L. First oncolytic virus approved for melanoma immunotherapy. Oncoimmunology. 2016;5(1): e1115641. https://doi.org/10.1080/2162402X.2015.1115641.

4. Boyiadzis MM, Kirkwood JM, Marshall JL, Pritchard CC, Azad NS, Gulley JL. Significance and implications of FDA approval of pembrolizumab for biomarker-defined disease. J Immunother Cancer. 2018;6(1):35. https://doi.org/10.1186/s40425-018-0342$\mathrm{x}$.

5. Kazandjian D, Suzman DL, Blumenthal G, Mushti S, He K, Libeg $\mathrm{M}$, et al. FDA approval summary: nivolumab for the treatment of metastatic non-small cell lung cancer with progression on or after platinum-based chemotherapy. Oncologist. 2016;21(5):634-42. https://doi.org/10.1634/theoncologist.2015-0507.

6. Cloughesy T, Petrecca K, Walbert T, Butowski N, Salacz M, Perry J, et al. LTBK-08. Toca 511 \& Toca FC versus standard of care in patients with recurrent high grade glioma. NeuroOncology. 2019;21(Supplement_6):vi284-vi. https://doi.org/10. 1093/neuonc/noz219.1199.

7. Weller M, Butowski N, Tran DD, Recht LD, Lim M, Hirte H, et al. Rindopepimut with temozolomide for patients with newly diagnosed, EGFRvIII-expressing glioblastoma (ACT IV): a 
randomised, double-blind, international phase 3 trial. Lancet Oncol. 2017;18(10):1373-85. https://doi.org/10.1016/S14702045(17)30517-X.

8. Reardon DA, Brandes AA, Omuro A, Mulholland P, Lim M, Wick A, et al. Effect of nivolumab vs bevacizumab in patients with recurrent glioblastoma. JAMA Oncol. 2020. https://doi.org/ 10.1001/jamaoncol.2020.1024 A recent phase III clinical using checkpoint inhibition that failed to show improvement over bevacizumab treatment.

9. Aspelund A, Antila S, Proulx ST, Karlsen TV, Karaman S, Detmar M, et al. A dural lymphatic vascular system that drains brain interstitial fluid and macromolecules. J Exp Med. 2015;212: 991-9. https://doi.org/10.1084/jem.20142290.

10. Louveau A, Smirnov I, Keyes TJ, Eccles JD, Rouhani SJ, Peske JD, et al. Structural and functional features of central nervous system lymphatic vessels. Nature. 2015;523:337-41. https://doi. org/10.1038/nature14432.

11. Zamvil SS, Steinman L. The T lymphocyte in experimental allergic encephalomyelitis. Annu Rev Immunol. 1990;8:579-621. https://doi.org/10.1146/annurev.iy.08.040190.003051.

12.• Engelhardt B, Vajkoczy P, Weller RO. The movers and shapers in immune privilege of the CNS. Nat Immunol. 2017;18:123-31. https://doi.org/10.1038/ni.3666 An excellent, up-to-date summary of the cellular and anatomical barriers to immune cell trafficking and antigen presentation in the central nervous system.

13. Carrithers MD, Visintin I, Kang SJ, Janeway CA Jr. Differential adhesion molecule requirements for immune surveillance and inflammatory recruitment. Brain. 2000;123:1092-101. https://doi. org/10.1093/brain/123.6.1092.

14. Iliff JJ, Wang M, Liao Y, Plogg BA, Peng W, Gundersen GA, et al. A paravascular pathway facilitates CSF flow through the brain parenchyma and the clearance of interstitial solutes, including amyloid $\beta$. Sci Transl Med. 2012;4:147ra11. https://doi.org/ 10.1126/scitranslmed.3003748.

15. Morris AWJ, Sharp MMG, Albargothy NJ, Fernandes R, Hawkes CA, Verma A, et al. Vascular basement membranes as pathways for the passage of fluid into and out of the brain. Acta Neuropathol. 2016;131:725-36. https://doi.org/10.1007/s00401016-1555-z.

16. Pfeiffer F, Schäfer J, Lyck R, Makrides V, Brunner S, SchaerenWiemers N, et al. Claudin-1 induced sealing of blood-brain barrier tight junctions ameliorates chronic experimental autoimmune encephalomyelitis. Acta Neuropathol. 2011;122:601-14. https://doi. org/10.1007/s00401-011-0883-2.

17. Kida S, Pantazis A, Weller RO. CSF drains directly from the subarachnoid space into nasal lymphatics in the rat. Anatomy, histology and immunological significance. Neuropathol Appl Neurobiol. 1993;19:480-8. https://doi.org/10.1111/j.1365-2990. 1993.tb00476.x.

18. Hatterer E, Davoust N, Didier-Bazes M, Vuaillat C, Malcus C, Belin MF, et al. How to drain without lymphatics? Dendritic cells migrate from the cerebrospinal fluid to the B-cell follicles of cervical lymph nodes. Blood. 2006;107:806-12. https://doi.org/10. 1182/blood-2005-01-0154.

19. Carare RO, Bernardes-Silva M, Newman TA, Page AM, Nicoll JAR, Perry VH, et al. Solutes, but not cells, drain from the brain parenchyma along basement membranes of capillaries and arteries: significance for cerebral amyloid angiopathy and neuroimmunology. Neuropathol Appl Neurobiol. 2008;34:13144. https://doi.org/10.1111/j.1365-2990.2007.00926.x.

20. Rennels ML, Gregory TF, Blaumanis OR, Fujimoto K, Grady PA. Evidence for a 'paravascular' fluid circulation in the mammalian central nervous system, provided by the rapid distribution of tracer protein throughout the brain from the subarachnoid space. Brain
Res. 1985;326:47-63. https://doi.org/10.1016/0006-8993(85) 91383-6.

21. Hawkes CA, Härtig W, Kacza J, Schliebs R, Weller RO, Nicoll $\mathrm{JA}$, et al. Perivascular drainage of solutes is impaired in the ageing mouse brain and in the presence of cerebral amyloid angiopathy. Acta Neuropathol. 2011;121:431-43. https://doi.org/10.1007/ s00401-011-0801-7.

22. Ellingson BM, Wen PY, Cloughesy TF. Modified criteria for radiographic response assessment in glioblastoma clinical Trials. Neurotherapeutics. 2017;14:307-20. https://doi.org/10.1007/ s13311-016-0507-6.

23. Wen PY, Macdonald DR, Reardon DA, Cloughesy TF, Sorensen AG, Galanis E, et al. Updated response assessment criteria for high-grade gliomas: response assessment in neuro-oncology working group. J Clin Oncol. 2010;28:1963-72. https://doi.org/ 10.1200/JCO.2009.26.3541.

24. Engelhardt B, Ransohoff RM. Capture, crawl, cross: the T cell code to breach the blood-brain barriers. Trends Immunol. 2012;33:579-89. https://doi.org/10.1016/j.it.2012.07.004.

25. Galea I, Bernardes-Silva M, Forse PA, Van Rooijen N, Liblau RS, Perry VH. An antigen-specific pathway for CD8 T cells across the blood-brain barrier. J Exp Med. 2007;204:2023-30. https://doi. org/10.1084/jem.20070064.

26. Kwok D, Okada H. T-Cell based therapies for overcoming neuroanatomical and immunosuppressive challenges within the glioma microenvironment. J Neurooncol. 2020;147(2):281-95. https:// doi.org/10.1007/s11060-020-03450-7 Up-to-date review of the innovations made in $\mathbf{T}$ cell-based therapy in order to overcome the barriers to immune cell entry into the CNS and immunosuppression in the glioma tumor microenvironment.

27. Brennan CW, Verhaak RGW, McKenna A, Campos B, Noushmehr H, Salama SR, et al. The somatic genomic landscape of glioblastoma. Cell. 2013;155:462-77. https://doi.org/10.1016/ j.cell.2013.09.034.

28. Johnson BE, Mazor T, Hong C, Barnes M, Aihara K, McLean $\mathrm{CY}$, et al. Mutational analysis reveals the origin and therapydriven evolution of recurrent glioma. Science. 2014;343:189-93. https://doi.org/10.1126/science.1239947.

29. Cadieux B, Ching TT, VandenBerg SR, Costello JF. Genomewide hypomethylation in human glioblastomas associated with specific copy number alteration, methylenetetrahydrofolate reductase allele status, and increased proliferation. Cancer Res. 2006;66:8469-76. https://doi.org/10.1158/0008-5472.CAN-061547.

30. Ma H, Zhao C, Zhao Z, Hu L, Ye F, Wang H, et al. Specific glioblastoma multiforme prognostic-subtype distinctions based on DNA methylation patterns. Cancer Gene Ther. 2019;27:1-13. https://doi.org/10.1038/s41417-019-0142-6.

31. Martinez R, Martin-Subero JI, Rohde V, Kirsch M, Alaminos M, Fernandez AF, et al. A microarray-based DNA methylation study of glioblastoma multiforme. Epigenetics. 2009;4:255-64. https:// doi.org/10.4161/epi.9130.

32. Patel AP, Tirosh I, Trombetta JJ, Shalek AK, Gillespie SM, Wakimoto H, et al. Single-cell RNA-seq highlights intratumoral heterogeneity in primary glioblastoma. Science. 2014;344(6190): 1396-401. https://doi.org/10.1126/science.1254257.

33. Muscat AM, Wong NC, Drummond KJ, Algar EM, Khasraw M, Verhaak R, et al. The evolutionary pattern of mutations in glioblastoma reveals therapy-mediated selection. Oncotarget. 2018;9: 7844-58. https://doi.org/10.18632/oncotarget.23541.

34. Li G, Wong AJ. EGF receptor variant III as a target antigen for tumor immunotherapy. Expert Rev Vaccines. 2008;7(7):977-85. https://doi.org/10.1586/14760584.7.7.977.

35. Huang J, Yu J, Tu L, Huang N, Li H, Luo Y. Isocitrate dehydrogenase mutations in glioma: from basic discovery to therapeutics 
development. Front Oncol. 2019;9:506. https://doi.org/10.3389/ fonc. 2019.00506

36. Chheda ZS, Kohanbash G, Okada K, Jahan N, Sidney J, Pecoraro $\mathrm{M}$, et al. Novel and shared neoantigen derived from histone 3 variant $\mathrm{H} 3.3 \mathrm{~K} 27 \mathrm{M}$ mutation for glioma $\mathrm{T}$ cell therapy. J Exp Med. 2018;215(1):141-57. https://doi.org/10.1084/jem. 20171046.

37. Lopez GY, Oberheim Bush NA, Phillips JJ, Bouffard JP, Moshel YA, Jaeckle K, et al. Diffuse midline gliomas with subclonal H3F3A K27M mutation and mosaic H3.3 K27M mutant protein expression. Acta Neuropathol. 2017;134(6):961-3. https://doi. org/10.1007/s00401-017-1780-0.

38. Solomon DA, Wood MD, Tihan T, Bollen AW, Gupta N, Phillips JJ, et al. Diffuse midline gliomas with histone H3-K27M mutation: a series of 47 cases assessing the spectrum of morphologic variation and associated genetic alterations. Brain Pathol. 2016;26(5):569-80. https://doi.org/10.1111/bpa.12336.

39. Nduom EK, Weller M, Heimberger AB. Immunosuppressive mechanisms in glioblastoma. Neuro Oncol. 2015;17(Suppl 7): vii9-vii14. https://doi.org/10.1093/neuonc/nov151.

40. Chongsathidkiet P, Jackson C, Koyama S, Loebel F, Cui X, Farber SH, et al. Sequestration of T cells in bone marrow in the setting of glioblastoma and other intracranial tumors. Nat Med. 2018;24(9):1459-68. https://doi.org/10.1038/s41591-018-0135-2 Recent discovery of mechanism by which GBM affects systemic immunity and the $T$ cell population.

41. Fecci PE, Mitchell DA, Whitesides JF, Xie W, Friedman AH, Archer GE, et al. Increased regulatory T-cell fraction amidst a diminished CD4 compartment explains cellular immune defects in patients with malignant glioma. Cancer Res. 2006;66(6):3294 302. https://doi.org/10.1158/0008-5472.CAN-05-3773.

42. Wing K, Sakaguchi S. Regulatory T cells exert checks and balances on self tolerance and autoimmunity. Nat Immunol. 2010;11(1):7-13. https://doi.org/10.1038/ni.1818.

43. Iglesia MD, Parker JS, Hoadley KA, Serody JS, Perou CM, Vincent BG. Genomic analysis of immune cell infiltrates across 11 tumor types. J Natl Cancer Inst. 2016;108(11). https://doi.org/ 10.1093/jnci/djw144.

44. Sica A, Schioppa T, Mantovani A, Allavena P. Tumour-associated macrophages are a distinct M2 polarised population promoting tumour progression: potential targets of anti-cancer therapy. Eur J Cancer. 2006;42(6):717-27. https://doi.org/10.1016/j.ejca.2006. 01.003 .

45. Veglia F, Perego M, Gabrilovich D. Myeloid-derived suppressor cells coming of age. Nat Immunol. 2018;19(2):108-19. https:// doi.org/10.1038/s41590-017-0022-x.

46. Kohanbash G, Okada H. Myeloid-derived suppressor cells (MDSCs) in gliomas and glioma-development. Immunol Investig. 2012;41(6-7):658-79. https://doi.org/10.3109/ 08820139.2012.689591.

47. Umansky V, Blattner C, Gebhardt C, Utikal J. The role of myeloid-derived suppressor cells (MDSC) in cancer progression. Vaccines (Basel). 2016;4(4). https://doi.org/10.3390/ vaccines 4040036 .

48. Anthony C, Mladkova-Suchy N, Adamson DC. The evolving role of antiangiogenic therapies in glioblastoma multiforme: current clinical significance and future potential. Expert Opin Investig Drugs. 2019;28(9):787-97. https://doi.org/10.1080/13543784. 2019.1650019.

49. Han J, Alvarez-Breckenridge CA, Wang QE, Yu J. TGF- $\beta$ signaling and its targeting for glioma treatment. Am J Cancer Res. 2015;5(3):945-55.

50. Chang N, Ahn SH, Kong DS, Lee HW, Nam DH. The role of STAT3 in glioblastoma progression through dual influences on tumor cells and the immune microenvironment. Mol Cell
Endocrinol. 2017;451:53-65. https://doi.org/10.1016/j.mce.2017. 01.004 .

51. Furtek SL, Backos DS, Matheson CJ, Reigan P. Strategies and approaches of targeting STAT3 for cancer treatment. ACS Chem Biol. 2016;11(2):308-18. https://doi.org/10.1021/acschembio. 5 b00945.

52. Yan J, Kong LY, Hu J, Gabrusiewicz K, Dibra D, Xia X, et al. FGL2 as a multimodality regulator of tumor-mediated immune suppression and therapeutic target in gliomas. J Natl Cancer Inst. 2015;107(8). https://doi.org/10.1093/jnci/djv137.

53. Grossman SA, Ye X, Lesser G, Sloan A, Carraway H, Desideri S, et al. Immunosuppression in patients with high-grade gliomas treated with radiation and temozolomide. Clin Cancer Res. 2011;17(16):5473-80. https://doi.org/10.1158/1078-0432.CCR11-0774.

54. Okada H, Weller M, Huang R, Finocchiaro G, Gilbert MR, Wick $\mathrm{W}$, et al. Immunotherapy response assessment in neuro-oncology: a report of the RANO working group. Lancet Oncol. 2015;16(15): e534-e42. https://doi.org/10.1016/S1470-2045(15)00088-1.

55. Desjardins A, Herndon JE, McSherry F, Ravelo A, Lipp ES, Healy P, et al. Single-institution retrospective review of patients with recurrent glioblastoma treated with bevacizumab in clinical practice. Health Sci Rep. 2019;2(4):e114. https://doi.org/10.1002/ hsr2.114.

56. Mueller S, Taitt JM, Villanueva-Meyer JE, Bonner ER, Nejo T, Lulla RR et al. Mass cytometry detects H3.3K27M-specific vaccine responses in diffuse midline glioma. J Clin Invest. 2020;In press.

57. Keskin DB, Anandappa AJ, Sun J, Tirosh I, Mathewson ND, Li S, et al. Neoantigen vaccine generates intratumoral $\mathrm{T}$ cell responses in phase Ib glioblastoma trial. Nature. 2019;565(7738):234-9. https://doi.org/10.1038/s41586-018-0792-9.

58. Wang J, Shen F, Yao Y, Wang LL, Zhu Y, Hu J. Adoptive cell therapy: a novel and potential immunotherapy for glioblastoma. Front Oncol. 2020;10:59. https://doi.org/10.3389/fonc.2020. 00059 .

59. Jena B, Dotti G, Cooper LJ. Redirecting T-cell specificity by introducing a tumor-specific chimeric antigen receptor. Blood. 2010;116(7):1035-44. https://doi.org/10.1182/blood-2010-01043737.

60. Finney HM, Akbar AN, Lawson AD. Activation of resting human primary $\mathrm{T}$ cells with chimeric receptors: costimulation from CD28, inducible costimulator, CD134, and CD137 in series with signals from the TCR zeta chain. J Immunol. 2004;172(1):104 13. https://doi.org/10.4049/jimmunol.172.1.104.

61. O'Rourke DM, Nasrallah MP, Desai A, Melenhorst JJ, Mansfield $\mathrm{K}$, Morrissette JJD, et al. A single dose of peripherally infused EGFRvIII-directed CAR T cells mediates antigen loss and induces adaptive resistance in patients with recurrent glioblastoma. Sci Transl Med. 2017;9:eaaa0984. https://doi.org/10.1126/ scitranslmed.aaa0984.

62. Goff SL, Morgan RA, Yang JC, Sherry RM, Robbins PF, Restifo NP, et al. Pilot trial of adoptive transfer of chimeric antigen receptor-transduced $\mathrm{T}$ cells targeting EGFRvIII in patients with glioblastoma. J Immunother. 2019;42(4):126-35. https://doi.org/ 10.1097/CJI.0000000000000260.

63. Thaci B, Brown CE, Binello E, Werbaneth K, Sampath P, Sengupta S. Significance of interleukin-13 receptor alpha 2targeted glioblastoma therapy. Neuro-Oncology. 2014;16(10): 1304-12. https://doi.org/10.1093/neuonc/nou045.

64. Brown CE, Badie B, Barish ME, Weng L, Ostberg JR, Chang $\mathrm{WC}$, et al. Bioactivity and safety of IL13Ralpha2-redirected chimeric antigen receptor CD8+ T cells in patients with recurrent glioblastoma. Clin Cancer Res. 2015;21(18):4062-72. https:// doi.org/10.1158/1078-0432.CCR-15-0428. 
65. Brown CE, Alizadeh D, Starr R, Weng L, Wagner JR, Naranjo A, et al. Regression of glioblastoma after chimeric antigen receptor Tcell therapy. N Engl J Med. 2016;375(26):2561-9. https://doi.org/ 10.1056/NEJMoa1610497.

66. Reardon DA, Desjardins A, Vredenburgh JJ, O'Rourke DM, Tran $\mathrm{DD}$, Fink KL, et al. Rindopepimut with bevacizumab for patients with relapsed EGFRvIII-expressing glioblastoma (ReACT): results of a double-blind randomized phase II trial. Clin Cancer Res. 2020;26(7):1586-94. https://doi.org/10.1158/1078-0432. CCR-18-1140.

67. Migliorini D, Dutoit V, Allard M, Grandjean Hallez N, Marinari E, Widmer V, et al. Phase I/II trial testing safety and immunogenicity of the multipeptide IMA950/poly-ICLC vaccine in newly diagnosed adult malignant astrocytoma patients. NeuroOncology. 2019;21(7):923-33. https://doi.org/10.1093/neuonc/ noz040.

68. Wen PY, Reardon DA, Armstrong TS, Phuphanich S, Aiken RD, Landolfi JC, et al. A randomized double-blind placebo-controlled phase II trial of dendritic cell vaccine ICT-107 in newly diagnosed patients with glioblastoma. Clin Cancer Res. 2019;25(19):5799 807. https://doi.org/10.1158/1078-0432.CCR-19-0261.

69. Wick W, van den Bent MJ. First results on the DCVax phase III trial: raising more questions than providing answers. NeuroOncology. 2018;20(10):1283-4. https://doi.org/10.1093/neuonc/ noy 125.

70. Liau LM, Ashkan K, Tran DD, Campian JL, Trusheim JE, Cobbs CS, et al. First results on survival from a large phase 3 clinical trial of an autologous dendritic cell vaccine in newly diagnosed glioblastoma. J Transl Med. 2018;16(1):142. https://doi.org/10.1186/ s12967-018-1507-6.

71. Peereboom DM, Nabors LB, Kumthekar P, Badruddoja MA, Fink KL, Lieberman FS, et al. Phase 2 trial of SL-701 in relapsed/ refractory $(\mathrm{r} / \mathrm{r})$ glioblastoma $(\mathrm{GBM})$ : correlation of immune response with longer-term survival. J Clin Oncol. 2018;36(15_suppl):2058. https://doi.org/10.1200/JCO.2018.36. 15 suppl.2058.

72. Reardon DA, Nayak L, Peters KB, Clarke JL, Jordan JT, Groot JFD, et al. Phase II study of pembrolizumab or pembrolizumab plus bevacizumab for recurrent glioblastoma (rGBM) patients. J Clin Oncol. 2018;36(15_suppl):2006. https://doi.org/10.1200/ JCO.2018.36.15_suppl.2006.

73. Sahebjam S, Forsyth P, Arrington J, Jaglal M, Tran ND, Etame $\mathrm{AB}$, et al. ATIM-18. A phase I trial of hypofractionated stereotactic irradiation (HFSRT) with pembrolizumab and bevacizumab in patients with recurrent high grade glioma (NCT02313272). Neuro-Oncol. 2017;19(suppl_6):vi30-vi. https://doi.org/10.1093/ neuonc/nox 168.113.

74. Ahmed NM, Brawley VS, Diouf O, Ghazi A, Yi J, Liu H, et al. Autologous HER2 CMV bispecific CAR T cells for progressive glioblastoma: results from a phase I clinical trial. J Clin Oncol. 2015;33(15_suppl):3008. https://doi.org/10.1200/jco.2015.33. 15_suppl.3008.

75. Lang FF, Conrad C, Gomez-Manzano C, Yung WKA, Sawaya R, Weinberg JS, et al. Phase I study of DNX-2401 (Delta-24-RGD) oncolytic adenovirus: replication and immunotherapeutic effects in recurrent malignant glioma. J Clin Oncol. 2018;36(14):141927. https://doi.org/10.1200/JCO.2017.75.8219.

76. Alonso MM, García-Moure M, Gonzalez-Huarriz M, Marigil M, Hernandez-Alcoceba R, Buñales M, et al. Abstract CT027: oncolytic virus DNX-2401 with a short course of temozolomide for glioblastoma at first recurrence: clinical data and prognostic biomarkers. Cancer Res. 2017;77(13 Supplement):CT027-CT. https://doi.org/10.1158/1538-7445.am2017-ct027.

77. Desjardins A, Gromeier M, Herndon JE, Beaubier N, Bolognesi $\mathrm{DP}$, Friedman $\mathrm{AH}$, et al. Recurrent glioblastoma treated with recombinant poliovirus. N Engl J Med. 2018;379(2):150-61. https://doi.org/10.1056/NEJMoa1716435.

78. Kalkanis SN, Aghi MK, Cloughsy TF, Kaptain G, Portnow J, Vogelbaum MA, et al. DDEL-06: Preliminary safety of Toca 511, a retroviral replicating vector, in patients with recurrent high grade glioma across three separate phase 1 studies. NeuroOncology. 2015;17(suppl_5):v74-v. https://doi.org/10.1093/ neuonc/nov212.06.

79. Cloughesy TF, Landolfi J, Hogan DJ, Bloomfield S, Carter B, Chen CC, et al. Phase 1 trial of vocimagene amiretrorepvec and 5-fluorocytosine for recurrent high-grade glioma. Sci Transl Med. 2016;8(341):341 ra75. https://doi.org/10.1126/scitranslmed. aad9784.

80. Cloughesy TF, Landolfi J, Vogelbaum MA, Ostertag D, Elder JB, Bloomfield S, et al. Durable complete responses in some recurrent high-grade glioma patients treated with Toca 511 + Toca FC. Neuro-Oncology. 2018;20(10):1383-92. https://doi.org/10.1093/ neuonc/noy075.

81. Todo T. ATIM-14. Results of phase II clinical trial of oncolytic herpes virus G47delta in patients with glioblastoma. NeuroOncology. 2019;21(Supplement_6):vi4-vi. https://doi.org/10. 1093/neuonc/noz175.014.

82. Clinical Trials. Viral therapy in treating patients with recurrent glioblastoma multiforme. 2020, January 2. https://clinicaltrials. gov/ct2/show/results/NCT00390299.

83. Geletneky K, Hajda J, Angelova AL, Leuchs B, Capper D, Bartsch AJ, et al. Oncolytic H-1 parvovirus shows safety and signs of immunogenic activity in a first phase I/IIa glioblastoma trial. Mol Ther. 2017;25(12):2620-34. https://doi.org/10.1016/j. ymthe.2017.08.016.

84. Zadeh G, Lang F, Daras M, Cloughesy T, Colman H, Ong S, et al. ATIM-24. Interim results of a phase II multicenter study of the conditionally replicative oncolytic adenovirus DNX-2401 with pembrolizumab (Keytruda) for recurrent glioblastoma; CAPTIVE study (KEYNOTE-192). Neuro-Oncology. 2018;20(suppl 6):vi6-vi. https://doi.org/10.1093/neuonc/noy148. 019.

85. Cloughesy TF, Brenner A, de Groot JF, Butowski NA, Zach L, Campian JL, et al. A randomized controlled phase III study of VB111 combined with bevacizumab vs bevacizumab monotherapy in patients with recurrent glioblastoma (GLOBE). Neuro-Oncology. 2020;22(5):705-17. https://doi.org/10.1093/neuonc/noz232.

86. Platten M, Schilling D, Bunse L, Wick A, Bunse T, Riehl D, et al. ATIM-33. NOA-16: A first-in-man multicenter phase I clinical trial of the German Neurooncology Working Group evaluating a mutation-specific peptide vaccine targeting IDH1R132H in patients with newly diagnosed malignant astrocytomas. NeuroOncol. 2018;20(suppl_6):vi8-9. https://doi.org/10.1093/neuonc/ noy 148.028.

87. Kieran MW, Goumnerova L, Manley P, Chi SN, Marcus KJ, Manzanera AG, et al. Phase I study of gene-mediated cytotoxic immunotherapy with AdV-tk as adjuvant to surgery and radiation for pediatric malignant glioma and recurrent ependymoma. Neuro-Oncology. 2019;21(4):537-46. https://doi.org/10.1093/ neuonc/noy202.

88. Zhang H, Ye ZL, Yuan ZG, Luo ZQ, Jin HJ, Qian QJ. New strategies for the treatment of solid tumors with CAR-T cells. Int J Biol Sci. 2016;12(6):718-29. https://doi.org/10.7150/ijbs. 14405 .

89. Bielamowicz K, Fousek K, Byrd TT, Samaha H, Mukherjee M, Aware N, et al. Trivalent CAR T cells overcome interpatient antigenic variability in glioblastoma. Neuro-Oncology. 2017;20: 506-18. https://doi.org/10.1093/neuonc/nox182.

90. Grada Z, Hegde M, Byrd T, Shaffer DR, Ghazi A, Brawley VS, et al. TanCAR: a novel bispecific chimeric antigen receptor for 
cancer immunotherapy. Mol Ther Nucleic Acids. 2013;2:e105. https://doi.org/10.1038/mtna.2013.32.

91. Hegde M, Mukherjee M, Grada Z, Pignata A, Landi D, Navai SA, et al. Tandem CAR T cells targeting HER 2 and IL13R $\alpha 2$ mitigate tumor antigen escape. J Clin Investig. 2016;126:3036-52. https:// doi.org/10.1172/JCI83416.

92. Morsut L, Roybal KT, Xiong X, Gordley RM, Coyle SM, Thomson M, et al. Engineering customized cell sensing and response behaviors using synthetic notch receptors. Cell. 2016;164: 780-91. https://doi.org/10.1016/j.cell.2016.01.012.

93. Roybal KT, Rupp LJ, Morsut L, Walker WJ, McNally KA, Park JS, et al. Precision tumor recognition by T cells with combinatorial antigen-sensing circuits. Cell. 2016;164:770-9. https://doi.org/10. 1016/j.cell.2016.01.011.

94. Mulazzani M, Fräßle SP, von Mücke-Heim I, Langer S, Zhou X, Ishikawa-Ankerhold $\mathrm{H}$, et al. Long-term in vivo microscopy of CAR T cell dynamics during eradication of CNS lymphoma in mice. Proc Natl Acad Sci U S A. 2019;116:24275-84. https://doi. org/10.1073/pnas.1903854116.

95. Nellan A, Rota C, Majzner R, Lester-McCully CM, Griesinger AM, Mulcahy Levy JM, et al. Durable regression of medulloblastoma after regional and intravenous delivery of anti-HER2 chimeric antigen receptor T cells. J ImmunoTher Cancer. 2018;6:30. https://doi.org/10.1186/s40425-018-0340-z.

96. Goldberg SB, Gettinger SN, Mahajan A, Chiang AC, Herbst RS, Sznol M, et al. Pembrolizumab for patients with melanoma or non-small-cell lung cancer and untreated brain metastases: early analysis of a non-randomised, open-label, phase 2 trial. Lancet Oncol. 2016;17:976-83. https://doi.org/10.1016/S1470-2045(16) 30053-5.

97. Long GV, Atkinson V, Lo S, Sandhu S, Guminski AD, Brown $\mathrm{MP}$, et al. Combination nivolumab and ipilimumab or nivolumab alone in melanoma brain metastases: a multicentre randomised phase 2 study. Lancet Oncol. 2018;19:672-81. https://doi.org/ 10.1016/S1470-2045(18)30139-6.

98. Tawbi HA, Forsyth PA, Algazi A, Hamid O, Hodi FS, Moschos SJ, et al. Combined nivolumab and ipilimumab in melanoma metastatic to the brain. N Engl J Med. 2018;379:722-30. https://doi. org/10.1056/NEJMoa1805453.

99. Klemm F, Maas RR, Bowman RL, Kornete M, Soukup K, Nassiri $\mathrm{S}$, et al. Interrogation of the microenvironmental landscape in brain tumors reveals disease-specific alterations of immune cells. Cell. 2020;181(7):1643-60 e17. https://doi.org/10.1016/j.cell. 2020.05.007.

100.• Friebel E, Kapolou K, Unger S, Nunez NG, Utz S, Rushing EJ, et al. Single-cell mapping of human brain cancer reveals tumorspecific instruction of tissue-invading leukocytes. Cell. 2020;181(7):1626-42 e20. https://doi.org/10.1016/j.cell.2020.04. 055 References $\mathbf{7 7}$ and $\mathbf{7 8}$ are recent groundbreaking studies detailing key differences in the tumor microenvironment between astrocytomas and brain metastases, which could explain the differing responses to immunotherapy in the two tumor types.

101. Lyle LT, Lockman PR, Adkins CE, Mohammad AS, Sechrest E, Hua E, et al. Alterations in pericyte subpopulations are associated with elevated blood-tumor barrier permeability in experimental brain metastasis of breast cancer. Clin Cancer Res. 2016;22(21): 5287-99. https://doi.org/10.1158/1078-0432.CCR-15-1836.

102. Quail DF, Joyce JA. The microenvironmental landscape of brain tumors. Cancer Cell. 2017;31(3):326-41. https://doi.org/10.1016/ j.ccell.2017.02.009.

103. Barajas RF Jr, Cha S. Metastasis in adult brain tumors. Neuroimaging Clin N Am. 2016;26(4):601-20. https://doi.org/ 10.1016/j.nic.2016.06.008.

104. Brahm CG, van Linde ME, Enting RH, Schuur M, Otten RHJ, Heymans MW, et al. The current status of immune checkpoint inhibitors in neuro-oncology: a systematic review. Cancers (Basel). 2020;12(3). https://doi.org/10.3390/cancers 12030586.

105. Gajewski TF, Schreiber H, Fu YX. Innate and adaptive immune cells in the tumor microenvironment. 2013;14:1014-22. https:// doi.org/10.1038/ni.2703.

106. Taggart D, Andreou T, Scott KJ, Williams J, Rippaus N, Brownlie RJ, et al. Anti-PD-1/anti-CTLA-4 efficacy in melanoma brain metastases depends on extracranial disease and augmentation of CD8(+) T cell trafficking. Proc Natl Acad Sci U S A. 2018;115(7):E1540-E9. https://doi.org/10.1073/pnas. 1714089115 One of the first demonstrations showing that the efficacy of immune checkpoint inhibition in the brain may rely on the presence of extracranial disease.

107. Nduom EK, Wei J, Yaghi NK, Huang N, Kong L-Y, Gabrusiewicz K, et al. PD-L1 expression and prognostic impact in glioblastoma. Neuro-Oncol. 2015;18:195-205. https://doi.org/ 10.1093/neuonc/nov172.

108. Goodman AM, Kato S, Bazhenova L, Patel SP, Frampton GM, Miller V, et al. Tumor mutational burden as an independent predictor of response to immunotherapy in diverse cancers. Mol Cancer Ther. 2017;16:2598-608. https://doi.org/10.1158/15357163.MCT-17-0386.

109. Luksza M, Riaz N, Makarov V, Balachandran VP, Hellmann MD, Solovyov A, et al. A neoantigen fitness model predicts tumour response to checkpoint blockade immunotherapy. Nature. 2017;551:517-20. https://doi.org/10.1038/nature24473.

110. McGranahan N, Furness AJS, Rosenthal R, Ramskov S, Lyngaa $\mathrm{R}$, Saini SK, et al. Clonal neoantigens elicit $\mathrm{T}$ cell immunoreactivity and sensitivity to immune checkpoint blockade. Science. 2016;351:1463-9. https://doi.org/10.1126/science.aaf1490.

111. Cloughesy TF, Mochizuki AY, Orpilla JR, Hugo W, Lee AH, Davidson TB, et al. Neoadjuvant anti-PD-1 immunotherapy promotes a survival benefit with intratumoral and systemic immune responses in recurrent glioblastoma. Nat Med. 2019;25:477-86. https://doi.org/10.1038/s41591-018-0337-7 Neoadjuvant design demonstrating biological impacts of anti-PD1 therapy in the GBM microenvironment.

112. Swartz AM, Batich KA, Fecci PE, Sampson JH. Peptide vaccines for the treatment of glioblastoma. J Neuro-Oncol. 2015;123(3): 433-40. https://doi.org/10.1007/s11060-014-1676-y.

113. Hilf N, Kuttruff-Coqui S, Frenzel K, Bukur V, Stevanović S, Gouttefangeas $\mathrm{C}$, et al. Actively personalized vaccination trial for newly diagnosed glioblastoma. Nature. 2019;565(7738):2405. https://doi.org/10.1038/s41586-018-0810-y.

114. Lichty BD, Breitbach CJ, Stojdl DF, Bell JC. Going viral with cancer immunotherapy. Nat Rev Cancer. 2014;14(8):559-67. https://doi.org/10.1038/nrc3770.

115. Martikainen M, Essand M. Virus-based immunotherapy of glioblastoma. Cancers (Basel). 2019;11(2). https://doi.org/10.3390/ cancers11020186.

116. Brown MC, Dobrikova EY, Dobrikov MI, Walton RW, Gemberling SL, Nair SK, et al. Oncolytic polio virotherapy of cancer. Cancer. 2014;120(21):3277-86. https://doi.org/10.1002/ cncr.28862.

117.• Chiocca EA, Nassiri F, Wang J, Peruzzi P, Zadeh G. Viral and other therapies for recurrent glioblastoma: is a 24-month durable response unusual? Neuro Oncol. 2019;21(1):14-25. https://doi. org/10.1093/neuonc/noy170 A recent review of previous virotherapy studies' survival data and patient stratification to determine if the often noted "tail" of long-term responders is demonstrative of true treatment efficacy.

118. Baker AT, Aguirre-Hernández C, Halldén G, Parker AL. Designer oncolytic adenovirus: coming of age. Cancers (Basel). 2018;10(6). https://doi.org/10.3390/cancers10060201.

119. Fueyo J, Gomez-Manzano C, Alemany R, Lee PS, McDonnell TJ, Mitlianga $\mathrm{P}$, et al. A mutant oncolytic adenovirus targeting the $\mathrm{Rb}$ 
pathway produces anti-glioma effect in vivo. Oncogene. 2000;19(1):2-12. https://doi.org/10.1038/sj.onc.1203251.

120. Jiang H, Gomez-Manzano C, Aoki H, Alonso MM, Kondo S, McCormick F, et al. Examination of the therapeutic potential of Delta-24-RGD in brain tumor stem cells: role of autophagic cell death. J Natl Cancer Inst. 2007;99(18):1410-4. https://doi.org/10. 1093/jnci/djm102.

121. Alonso MM, Gomez-Manzano C, Bekele BN, Yung WK, Fueyo J. Adenovirus-based strategies overcome temozolomide resistance by silencing the O6-methylguanine-DNA methyltransferase promoter. Cancer Res. 2007;67(24):11499-504. https://doi.org/10. 1158/0008-5472.CAN-07-5312.

122. Kleijn A, van den Bossche W, Haefner ES, Belcaid Z, BurghoornMaas C, Kloezeman JJ, et al. The sequence of Delta24-RGD and TMZ administration in malignant glioma affects the role of CD8. Mol Ther Oncolyt. 2017;5:11-9. https://doi.org/10.1016/j.omto. 2017.02.002.

123. Todo T. ATIM-14. Results of phase II clinical trial of oncolytic herpes virus g47ठ in patients with glioblastoma. Neuro-Oncol. 2019;21(Supplement_6):vi4-vi. https://doi.org/10.1093/neuonc/ noz175.014.

124. Perez OD, Logg CR, Hiraoka K, Diago O, Burnett R, Inagaki A, et al. Design and selection of Toca 511 for clinical use: modified retroviral replicating vector with improved stability and gene expression. Mol Ther. 2012;20(9):1689-98. https://doi.org/10.1038/ mt.2012.83.

125. Ghosh D, Nandi S, Bhattacharjee S. Combination therapy to checkmate glioblastoma: clinical challenges and advances. Clin Transl Med. 2018;7(1):33. https://doi.org/10.1186/s40169-0180211-8.

126. Sengupta S, Katz SC, Sengupta S, Sampath P. Glycogen synthase kinase 3 inhibition lowers PD-1 expression, promotes long-term survival and memory generation in antigen-specific CAR-T cells. Cancer Lett. 2018;433:131-9. https://doi.org/10.1016/j.canlet. 2018.06.035.

127. Cherkassky L, Morello A, Villena-Vargas J, Feng Y, Dimitrov DS, Jones DR, et al. Human CAR T cells with cell-intrinsic PD-
1 checkpoint blockade resist tumor-mediated inhibition. J Clin Investig. 2016;126:3130-44. https://doi.org/10.1172/JCI83092.

128. Jiang H, Rivera-Molina Y, Gomez-Manzano C, Clise-Dwyer K, Bover L, Vence LM, et al. Oncolytic adenovirus and tumortargeting immune modulatory therapy improve autologous cancer vaccination. Cancer Res. 2017;77(14):3894-907. https://doi.org/ 10.1158/0008-5472.CAN-17-0468.

129. Kamran N, Kadiyala P, Saxena M, Candolfi M, Li Y, MorenoAyala MA, et al. Immunosuppressive myeloid cells' blockade in the glioma microenvironment enhances the efficacy of immunestimulatory gene therapy. Mol Ther. 2017;25(1):232-48. https:// doi.org/10.1016/j.ymthe.2016.10.003 Recent study demonstrating that myeloid-derived suppressor cells mediate suppression of immune cells activation, and their blockade causes improved response to immunotherapy.

130. Aquino D, Gioppo A, Finocchiaro G, Bruzzone MG, Cuccarini V. MRI in glioma immunotherapy: evidence, pitfalls, and perspectives. J Immunol Res. 2017;2017:5813951-16. https://doi.org/10. $1155 / 2017 / 5813951$.

131. Yaghoubi SS, Jensen MC, Satyamurthy N, Budhiraja S, Paik D, Czernin J, et al. Noninvasive detection of therapeutic cytolytic $\mathrm{T}$ cells with 18 F-FHBG PET in a patient with glioma. Nat Clin Pract Oncol. 2009;6:53-8. https://doi.org/10.1038/ncponc1278.

132. Venneti S, Lopresti BJ, Wiley CA. Molecular imaging of microglia/macrophages in the brain. GLIA. 2013;61:10-23. https://doi.org/10.1002/glia.22357.

133. Tourdias T, Roggerone S, Filippi M, Kanagaki M, Rovaris M, Miller DH, et al. Assessment of disease activity in multiple sclerosis phenotypes with combined gadolinium- and superparamagnetic iron oxide-enhanced MR imaging. Radiology. 2012;264:225-33. https://doi.org/10.1148/radiol. 12111416.

Publisher's Note Springer Nature remains neutral with regard to jurisdictional claims in published maps and institutional affiliations. 